\title{
Parental and neonatal risk factors for atopy, airway hyper-responsiveness, and asthma
}

\author{
Malcolm R Sears, M David Holdaway, Erin M Flannery, G Peter Herbison, Phil A Silva
}

Department of Medicine, McMaster University, Hamilton, Ontario, Canada

M R Sears

University of Otago

Medical School,

Dunedin, New

Zealand: Department

of Paediatrics and

Child Health

M D Holdaway

P A Silva

\section{Department of \\ Medicine \\ E M Flannery}

Department of

Preventive and Social

Medicine

G P Herbison

Correspondence to:

Professor Malcolm R Sears, Firestone Regional Chest

and Allergy Unit, St Joseph's

Hospital/McMaster

University, 50 Charlton

Avenue E, Hamilton, Ontario

L8N 4A6, Canada.

Accepted 25 June 1996

\begin{abstract}
Background-Previous studies have not resolved the importance of several potential risk factors for the development of childhood atopy, airway hyperresponsiveness, and wheezing, which would allow the rational selection of interventions to reduce morbidity from asthma. Risk factors for these disorders were examined in a birth cohort of 1037 New Zealand children.

Methods-Responses to questions on respiratory symptoms and measurements of lung function and airway responsiveness were obtained every two to three years throughout childhood and adolescence, with over $85 \%$ cohort retention at age 18 years. Atopy was determined by skin prick tests at age 13 years. Relations between parental and neonatal factors, the development of atopy, and features of asthma were determined by comparison of proportions and logistic regression.

Results-Male sex was a significant independent predictor for atopy, airway hyper-responsiveness, hay fever, and asthma. A positive family history, especially maternal, of asthma strongly predicted childhood atopy, airway hyperresponsiveness, asthma, and hay fever. Maternal smoking in the last trimester was correlated with the onset of childhood asthma by the age of 1 year. Birth in the winter season increased the risk of sensitisation to cats. Among those with a parental history of asthma or hay fever, birth in autumn and winter also increased the risk of sensitisation to house dust mites. The number of siblings, position in the family, socioeconomic status, and birth weight were not consistently predictive of any characteristic of asthma.

Conclusions-Male sex, parental atopy, and maternal smoking during pregnancy are risk factors for asthma in young children. Children born in winter exhibit a greater prevalence of sensitisation to cats and house dust mites. These data suggest possible areas for intervention in children at risk because of parental atopy. (Arch Dis Child 1996;75:392-398)
\end{abstract}

Keywords: asthma, atopy, airway hyper-responsiveness, family history.

Childhood asthma imposes a significant economic and lifestyle burden. " Certain risk factors for the development of asthma are established, but others are less clearly identified. $^{2-4}$ Parental atopy and asthma, ${ }^{5-7}$ family size, ${ }^{8}$ birth order, ${ }^{9}$ neonatal exposure to allergens, ${ }^{10-13}$ environmental tobacco smoke, ${ }^{7}{ }^{14-18}$ and low birth weight and prematurity $^{1920}$ are suggested determinants, but conflicting results have been reported. The conclusive identification of risk factors may lead to strategies to minimise these risks and so decrease the morbidity due to asthma.

Cigarette smoke is the most common indoor pollutant to which children are exposed. ${ }^{14}$ Many studies suggest an increased risk of asthma or wheezing in children exposed to cigarette smoke, especially maternal smoking, ${ }^{31216}{ }^{1821-24}$ with a dose-response relationship. ${ }^{12}$ Airway responsiveness to methacholine in Italian girls was related to both maternal (odds ratio (OR) 2.92 , 95\% confidence interval (CI) 1.43 to 5.95) and paternal (OR 2.59, $95 \%$ CI 1.36 to 4.95$)$ smoking with a dose-response relationship, but no increased risk was seen in boys. ${ }^{25}$ This suggests either that girls are more susceptible to exposure to cigarette smoke or that other risk factors in boys (for example, increased atopy) overshadow any effect of passive smoking.

Some studies have suggested that asthma is associated with higher ${ }^{26}$ or lower ${ }^{27}$ socioeconomic status, whereas others show no consistent association. ${ }^{72}{ }^{28}$ Low socioeconomic status was not a risk factor for wheeze in Danish infants in the first 18 months $^{22}$ or for increased airway responsiveness in Australian children. ${ }^{29}$ There may be considerable confounding of socioeconomic status with parental smoking. ${ }^{30}$

Atopy is an almost universal characteristic of persistent childhood asthma. The development of atopy has been variably associated with season of birth. ${ }^{9-12}$ Risks for grass sensitisation have been reported to be higher among children born in spring ${ }^{91}$ or reaching the age of 3 months in the grass pollen season, ${ }^{13}$ whereas others have found no influence of season of birth. ${ }^{11}$ Asthma is more common in Swedish children born in the summer months, ${ }^{32}$ but in New Zealand children with asthma of sufficient severity to be admitted to hospital, no relation was found between month of birth and risk of asthma. ${ }^{33}$

Family size and birth order may affect atopy and asthma. Von Mutius et al found that, after controlling for confounders, the prevalence of atopy (positive skin tests) decreased with an increasing number of siblings. ${ }^{8}$ The OR for atopy with one sibling was 0.96 , decreasing to $0.67(p=0.005)$ for five or more siblings. Oth- 
ers, however, have reported asthma to be less common in first born children. ${ }^{9}$

Birth weight has been reported to influence the risk of the development of asthma. In Danish children, after adjusting for socioeconomic status, sex, and maternal smoking, the OR for wheeze was 2.3 for those with a birth weight less than $2500 \mathrm{~g} .{ }^{12}$ Increased ORs for asthma (ranging from 2.8 to 3.5) were also found for low birth weight in Austria ${ }^{34}$ and Germany ${ }^{35}$. Low birth weight was related to house dust mite sensitisation in the Isle of Wight population (OR 3.4, 95\% CI 1.0 to 11.7$)^{21}$ and is reported to be associated with increased airway responsiveness to histamine ${ }^{36}$ or exercise. ${ }^{37}$ Aberdeen children, however, showed no relation between birth weight or prematurity and atopy. $^{38}$

Hence there remains uncertainty as to the relation between many potential risk factors affecting newborn infants and young children and the development of persistent asthma in childhood and adolescence. To further identify these putative risk factors for asthma we examined relations among parental, neonatal, and perinatal characteristics and the development of atopy, airway hyper-responsiveness, and asthma-like symptoms in a longitudinal epidemiological study of a birth cohort of $1037 \mathrm{New}$ Zealand children followed up to age 18 years.

\section{Methods}

\section{SUBJECTS}

Between 1 April 1972 and 31 March 1973, 1661 children were born in Dunedin's one maternity hospital. ${ }^{39}$ Of these, 1139 children residing in Otago province at age 3 years were invited to participate in a longitudinal multidisciplinary study of health and development. Those 1037 enrolled (91\% of those eligible) did not differ from the cohort of 1661 children with respect to recorded perinatal and postnatal factors, except that there were fewer children of lower socioeconomic status in the enrolled sample.

\section{INVESTIGATIONS}

Parental and neonatal characteristics were documented in all 1661 children as part of a cross sectional neonatal study. ${ }^{39}$ Those children enrolled in the longitudinal study were seen every two or three years within one month of their birthday for detailed medical and developmental assessment. Over $85 \%$ of the 1037 children were available for review at age 18 years. Parental smoking habits in the perinatal period were recalled when the child was aged 3 years. The family history of asthma and atopic disease and limited information on the child's respiratory symptoms were obtained from the accompanying adult (usually the mother) when the child was 7 years old. ${ }^{40} \mathrm{~A}$ more detailed retrospective history of wheezing, whether diagnosed as asthma or accompanying respiratory infections, recurrent coughing, and manifestations of atopy including 'hay fever' and eczema was obtained at the age of 9 years by a questionnaire administered to the parent by a doctor. ${ }^{41}$
Spirometry was undertaken at each review from 9 to 18 years, recording the best of three acceptable vital capacity (VC) and forced expired volume in one second $\left(\mathrm{FEV}_{1}\right)$ measurements obtained without recent (within six hours) use of any bronchodilator. ${ }^{42}$ A Godart water sealed spirometer was used at ages 9 to 15 years and a Morgan rolling seal spirometer with computerised output at age 18 years.

An abbreviated validated four dose five breath methacholine inhalation challenge was first undertaken at the age of 9 years using concentrations increasing in tenfold steps from 0.025 to $25.0 \mathrm{mg} / \mathrm{ml}^{42}$ Children who showed significant airflow obstruction on initial spirometry $\left(\mathrm{FEV}_{1} / \mathrm{VC}\right.$ less than $\left.75 \%\right)$ were not challenged with methacholine, but were restudied 10 minutes after the inhalation of nebulised salbutamol $5 \mathrm{mg} / \mathrm{ml}$ inhaled by tidal breathing for two minutes.

At ages $11,13,15$, and 18 years the child was questioned about symptoms over the preceding two or three years. Methacholine challenge was repeated at 11,13 , and 15 years, but at 18 years bronchodilator responsiveness was determined in each consenting subject.

Skin prick testing to 11 common allergens was performed in 714 subjects at age 13 years using house dust mite (Dermatophagoides pteronyssinus) (Bencard, UK), grass, cat, dog, horse, kapok, wool, Aspergillus fumigatus, alternaria, penicillium, and cladosporium (all supplied by Hollister-Stier, USA). ${ }^{43}$ Those tested were representative of all children seen at age 13 years and of the original sample of 1037 children.

\section{DEFINITIONS}

'Symptoms consistent with asthma' in the children were defined as recurrent wheeze or whistling in the chest, whether or not any provoking allergen, infection, or other cause was identified and whether or not wheezing was labelled as asthma. A parental history of asthma, however, was considered positive only if 'asthma' was reported as such. 'Hay fever' was defined in the questionnaire as 'allergy of eyes or nose, causing sneezing, itching or watery eyes or nose'. 'Atopy' was defined as one or more positive skin tests with a maximum weal diameter at least $2 \mathrm{~mm}$ greater than that produced by the diluent control. ${ }^{43}$ Airway hyper-responsiveness was recorded if the methacholine $\mathrm{PC}_{20} \mathrm{FEV}_{1}$ was less than or equal to $8 \mathrm{mg} / \mathrm{ml}$. Subjects who did not perform the methacholine challenge because their initial $\mathrm{FEV}_{1} / \mathrm{VC}$ ratio was $<75 \%$, and who showed $>10 \%$ increase in $\mathrm{FEV}_{1}$ after the inhalation of nebulised salbutamol, were also considered hyper-responsive. ${ }^{42}$

\section{STATISTICAL ANALYSES}

\section{Univariate analysis}

Relationships between symptoms of asthma, atopy, and airway responsiveness were related to family history by comparisons of proportions using $\chi^{2}$ tests. Smoking by the mother or father was analysed by trimester of pregnancy 
Table 1 Percentage of 714 children skin tested with common inhaled allergens at age 13 years showing atopy (any positive test $\geqslant 2 \mathrm{~mm}$ weal) in relation to different parental histories of asthma or hay fever

\begin{tabular}{lrlll}
\hline & \multicolumn{4}{l}{ Percentage of children with atopy } \\
\cline { 3 - 5 } Parent characteristic & No at risk & $\begin{array}{l}\text { Parental history } \\
\text { positive }\end{array}$ & $\begin{array}{l}\text { Parental history } \\
\text { negative }\end{array}$ & p Value \\
\hline Asthma & & & & \\
Father & 63 & 42.9 & 37.7 & 0.420 \\
Mother & 60 & 51.7 & 36.9 & 0.024 \\
Either & 116 & 46.6 & 36.5 & 0.042 \\
Both & 7 & 57.1 & 38.0 & 0.300 \\
Hay fever & & & 36.8 & 0.045 \\
Father & 83 & 48.2 & 36.4 & 0.058 \\
Mother & 142 & 45.1 & 35.4 & 0.019 \\
Either & 205 & 44.9 & 37.5 & 0.041 \\
Both & 20 & 60.0 & 35.2 & 0.013 \\
Asthma or hay fever in either parent & 208 & 45.2 &
\end{tabular}

Number at risk is number of children whose parent(s) had the listed characteristic.

and the three months after birth and was related to the age of onset of symptoms. Birth weights, grouped by $500 \mathrm{~g}$ increments, were related to respiratory symptoms reported to age 9 years and to measurements of lung function $\left(\mathrm{FEV}_{1}, \mathrm{VC}\right.$, and $\mathrm{FEV}_{1} / \mathrm{VC}$ ratio), airway responsiveness $\left(\mathrm{PC}_{20} \mathrm{FEV}\right.$ less than or equal to $8 \mathrm{mg} / \mathrm{ml}$ and absolute level of $\mathrm{PC}_{20} \mathrm{FEV}_{1}$ ), and atopy.

Multivariate analysis

A series of logistic regressions was performed to determine which parental and perinatal factors were independently related to the development of features of asthma or atopy, or both. The outcome (dependent) variables were symptoms to age 9 years, symptoms at any age from 9 to 18 years, hay fever at any age from 9 to 18 years, airway hyper-responsiveness at any age from 9 to 15 years, atopy (any skin test $\geqslant 2$ $\mathrm{mm}$ weal), and reactivity to house dust mite and cats. The predictor (independent) variables were the parental history of asthma or hay fever, or both, sex of child, season of birth, birth weight (using 3000-3499 $\mathrm{g}$ as the reference group), family socioeconomic status at birth, position in family, and exposure to parental cigarette smoking. The models were fitted in a two stage process. All independent variables were included in the first stage. To reduce the number of children excluded because of missing values, only those variables appearing likely to be related ( $\mathrm{p}<0.1$ approximately) in the first stage were included in the second stage.

\section{Results}

INFLUENCE OF FAMILY HISTORY

The likelihood of a child being atopic by skin test was strongly correlated with maternal asthma and with hay fever in either parent (table 1). If one parent had either asthma or hay fever, $45.2 \%$ of children were atopic compared with $35.2 \%$ of those with no such parental history $(\mathrm{p}=0.013)$.

There were strong relations between maternal asthma, hay fever, or both and these disorders in the children. This relation also existed for paternal hay fever but not paternal asthma (table 2). If one parent had either asthma or hay fever, $29.0 \%$ of children had symptoms of asthma compared with $20.0 \%$ of those with no parental history of asthma $(p=0.004)$, and $55.0 \%$ of children had hay fever compared with $37.0 \%$ of those with no parental history $(p=0.001)$. Similarly, there were significant relations between maternal asthma or hay fever, or both, or paternal hay fever, and airway hyper-responsiveness at age 9 years, or at any age between 9 and 15 years (table 3). These relations were stronger if both parents had asthma. The likelihood of showing airway hyper-responsiveness on all occasions tested between 9 and 15 years was increased if both parents had asthma $(14.3 v 2.2 \%, \mathrm{p}=0.03)$, or hay fever $(8.0 v 2.1 \%, \mathrm{p}=0.05)$, or one parent had asthma or hay fever $(3.9 v 1.6 \%, \mathrm{p}=0.04)$.

\section{INFLUENCE OF PARENTAL SMOKING}

Symptoms of asthma occurring by the age of 1 year significantly correlated with maternal smoking in the last trimester of pregnancy $(p=0.049)$. There were consistent trends for higher prevalences of symptoms throughout all early childhood years to the age of 9 years if the mother smoked more than 20 cigarettes each day during the first and second trimesters of pregnancy, with an increase in the prevalence of wheezing from between 10 and $15 \%$ in children not exposed to smoke to between 20 and $25 \%$ in those exposed to smoke (not tabulated). These trends did not achieve statistical significance. Regarding maternal smoking in the first three months after delivery, there was a trend to more wheeze in children of heavy smokers (14.9 $v 6.1 \%$ in non-smokers, $\mathrm{p}=$ $0.075)$. There was no correlation between

Table 2 Percentage of children reporting diagnosed asthma or hay fever at any time to age 18 years in relation to a positive or negative parental history of asthma and hay fever

\begin{tabular}{|c|c|c|c|c|c|c|c|}
\hline & \multirow[b]{2}{*}{$\begin{array}{l}\text { No at } \\
\text { risk }\end{array}$} & \multicolumn{3}{|c|}{ Percentage of children with asthma } & \multicolumn{3}{|c|}{ Percentage of children with hay fever } \\
\hline & & $\begin{array}{l}\text { Parental history } \\
\text { positive }\end{array}$ & $\begin{array}{l}\text { Parental history } \\
\text { negative }\end{array}$ & p Value & $\begin{array}{l}\text { Parental history } \\
\text { positive }\end{array}$ & $\begin{array}{l}\text { Parental history } \\
\text { negative }\end{array}$ & $p$ Value \\
\hline \multicolumn{8}{|l|}{ Asthma } \\
\hline Father & 77 & 27.3 & 22.2 & 0.30 & 48.7 & 41.6 & 0.23 \\
\hline Mother & 69 & 43.5 & 20.8 & 0.00002 & 65.2 & 40.2 & 0.00006 \\
\hline Either & 139 & 33.1 & 20.6 & 0.0013 & 55.1 & 39.8 & 0.0009 \\
\hline Both & 7 & 71.4 & 22.2 & 0.0019 & 85.7 & 41.9 & 0.019 \\
\hline \multicolumn{8}{|l|}{ Hay fever } \\
\hline Father & 101 & 32.7 & 21.3 & 0.010 & 60.4 & 39.8 & 0.00008 \\
\hline Mother & 169 & 28.4 & 21.2 & 0.045 & 58.6 & 38.2 & 0.00001 \\
\hline Either & 247 & 28.3 & 20.3 & 0.011 & 56.7 & 36.4 & 0.00001 \\
\hline Both & 23 & 47.8 & 21.9 & 0.0033 & 87.0 & 41.0 & 0.00001 \\
\hline Asthma or hay fever in either parent & 252 & 29.0 & 20.0 & 0.0041 & 55.0 & 37.0 & 0.00001 \\
\hline
\end{tabular}

Number at risk is number of children whose parent(s) had the listed characteristic. 
Table 3 Percentage of children showing hyperresponsiveness $\left(P C_{20} \leqslant 8 \mathrm{mg} / \mathrm{ml}\right)$ at age 9 years and at any test between the ages of 9 and 15 years, in relation to a positive or negative parental history of asthma and hay fever

\begin{tabular}{|c|c|c|c|c|c|c|c|c|}
\hline & \multirow[b]{2}{*}{$\begin{array}{l}\text { No at } \\
\text { risk }\end{array}$} & \multicolumn{3}{|c|}{$\begin{array}{l}\text { Percentage of children with } P C_{20} \leqslant 8 \mathrm{mg} / \mathrm{ml} \text { at age } \\
9 \text { years }\end{array}$} & \multirow[b]{2}{*}{$\begin{array}{l}\text { No at } \\
\text { risk }\end{array}$} & \multicolumn{3}{|c|}{$\begin{array}{l}\text { Percentage of children with } P C_{20} \leqslant 8 \mathrm{mg} / \mathrm{ml} \text { at } 9-15 \\
\text { years }\end{array}$} \\
\hline & & $\begin{array}{l}\text { Parental history } \\
\text { positive }\end{array}$ & $\begin{array}{l}\text { Parental history } \\
\text { negative }\end{array}$ & $p$ Value & & $\begin{array}{l}\text { Parental history } \\
\text { positive }\end{array}$ & $\begin{array}{l}\text { Parental history } \\
\text { negative }\end{array}$ & p Value \\
\hline \multicolumn{9}{|l|}{ Asthma } \\
\hline Father & 65 & 24.6 & 16.3 & 0.086 & 77 & 24.7 & 19.0 & 0.23 \\
\hline Mother & 60 & 26.7 & 16.1 & 0.037 & 69 & 36.2 & 18.1 & 0.003 \\
\hline Either & 118 & 22.9 & 15.9 & 0.063 & 139 & 28.1 & 17.9 & 0.006 \\
\hline Both & 7 & 71.4 & 16.5 & 0.001 & 7 & 71.4 & 19.1 & 0.005 \\
\hline \multicolumn{9}{|l|}{ Hay fever } \\
\hline Father & 84 & 23.8 & 16.1 & 0.077 & 104 & 29.8 & 18.2 & 0.005 \\
\hline Mother & 152 & 21.7 & 15.8 & 0.082 & 174 & 27.0 & 17.7 & 0.006 \\
\hline Either & 216 & 21.8 & 15.1 & 0.027 & 253 & 26.5 & 16.7 & 0.001 \\
\hline Both & 20 & 30.0 & 16.6 & 0.116 & 25 & 44.0 & 18.8 & 0.002 \\
\hline Asthma or hay fever in either parent & 223 & 22.0 & 14.9 & 0.018 & 257 & 26.5 & 16.7 & 0.001 \\
\hline
\end{tabular}

Number at risk is number of children whose parent(s) had the listed characteristic.

Table 4 Gender differences in asthma and wheezing

\begin{tabular}{|c|c|c|c|c|c|c|}
\hline \multirow{2}{*}{$\begin{array}{l}\text { Age } \\
\text { (years) }\end{array}$} & \multicolumn{3}{|c|}{ Current asthma (\%) } & \multicolumn{3}{|c|}{ Current wheezing (\%) } \\
\hline & Male & Female & $M: F$ & Male & Female & $M: F$ \\
\hline 9 & 9.1 & 5.9 & $1.54: 1$ & 22.4 & 18.9 & 1.19:1 \\
\hline 11 & 12.9 & 6.3 & $2.05: 1$ & 22.1 & 14.4 & $1.53: 1$ \\
\hline 13 & 14.7 & 8.7 & $1.69: 1$ & 39.5 & 33.8 & $1.17: 1$ \\
\hline 15 & 16.1 & 12.9 & $1.25: 1$ & 37.9 & 33.8 & $1.12: 1$ \\
\hline 18 & 14.0 & 15.6 & $0.90: 1$ & 49.0 & 61.3 & $0.80: 1$ \\
\hline
\end{tabular}

maternal smoking after the child was aged 3 months and symptoms of asthma at any age, or between paternal smoking and childhood symptoms at any age.

\section{INFLUENCE OF MONTH OF BIRTH}

By univariate analysis there was no correlation between the month of birth and diagnosis of asthma $(p=0.39)$, wheezing $(p=0.27)$, or airway hyper-responsiveness to methacholine or salbutamol $(p=0.89)$, nor between season of birth (summer, autumn, winter, spring) and these outcomes, although only $15.0 \%$ of children sensitive to mites were born during summer $(p=0.06)$.

\section{INFLUENCE OF BIRTH ORDER}

Of 868 subjects providing this information at age 18 years, $322(37.1 \%)$ were first born children, $276(31.8 \%)$ were second born children, and $270(31.1 \%)$ were third or later in their family. There was no correlation between being first born and atopy $(p=0.21)$, sensitivity to house dust mite $(p=0.62)$ or to cats ( $p=0.18)$, or to the development of symptoms of asthma $(p=0.98)$. Comparing first or second born children with those later born showed no association with atopy $(p=0.13)$ or sensitivity to house dust mites $(p=0.55)$, but there was an apparent negative relation with sensitivity to cats, those first or second born being significantly less likely $(9.9 v 16.1 \%)$ to be sensitive to cats $(p=0.03)$.

INFLUENCE OF GENDER

There was a male predominance in reported diagnosed asthma and in wheezing symptoms until the age of 18 years, when the gender difference reversed (table 4).

\section{INFLUENCE OF BIRTH WEIGHT}

Birth weights were normally distributed between 1420 and $5400 \mathrm{~g} ; 50$ subjects were less than $2500 \mathrm{~g}$ and 11 less than $2000 \mathrm{~g}$. There was no significant relation between birth weight and diagnosed asthma to age 9 years ( $p$ $=0.14$ ), ever having wheezed to age 9 years ( $p$ $=0.23), \mathrm{FEV}_{1} / \mathrm{VC}$ ratio grouped by $5 \%$ decrements from less than or equal to $90 \%$ to less than $75 \%(p=0.33)$ at age 9 years, or to asthma reported ever to age 18 years $(p=$ 0.092 ), for boys and girls together or separately. There was no significant relation between birth weight and the presence or degree of airway hyper-responsiveness (to either methacholine or salbutamol) at age 9 years. Children of low birth weight did not have more airflow obstruction; rather, a slight trend for those with lower birth weight to have higher $\mathrm{FEV}_{1}$ /VC ratios at age 9 years was observed. There was no report of diagnosed asthma in those of birth weight less than $2000 \mathrm{~g}$. The reference group with the median birth weight $(3000-3499 \mathrm{~g})$ had the highest prevalence of diagnosed asthma. All other birth weight groups had lower, rather than increased, ORs for asthma, but none was significantly different to 1.0 (table 5). There was no significant difference in ORs for boys and girls.

Table 5 Relation between birth weight, atopy, and reported diagnosed asthma and wheeze at age 9 years, and at any age to 18 years, in New Zealand children

\begin{tabular}{|c|c|c|c|c|c|c|}
\hline Birth weight $(g)$ & $\begin{array}{l}\text { No of births in } \\
\text { full cohort }\end{array}$ & $\begin{array}{l}\text { Atopy (\% of those } \\
\text { tested at } 13 \text { years) }\end{array}$ & $\begin{array}{l}\text { Reported wheeze to } 9 \\
\text { years }(\%)(n=815)\end{array}$ & $\begin{array}{l}\text { Reported asthma to } 9 \\
\text { years (\%) }(n=815)\end{array}$ & $\begin{array}{l}\text { Reported asthma to } 18 \\
\text { years }(\%)(n=1002)\end{array}$ & $\begin{array}{l}\text { Odds ratio for asthma to } \\
18 \text { years }(95 \% \mathrm{CI})\end{array}$ \\
\hline $\begin{array}{l}<2500 \\
2500-2999 \\
3000-3499 \\
3500-3999 \\
4000-4499 \\
\geqslant 4500 \\
\text { Total } \\
\text { p Value }\end{array}$ & $\begin{array}{r}50 \\
171 \\
380 \\
324 \\
99 \\
13 \\
1037\end{array}$ & $\begin{array}{c}37.1 \\
30.4 \\
44.2 \\
36.4 \\
30.7 \\
0 \\
37.4 \\
0.027\end{array}$ & $\begin{array}{l}21.4 \\
22.4 \\
29.6 \\
29.3 \\
34.9 \\
44.4 \\
28.7 \\
0.232\end{array}$ & $\begin{array}{c}2.3 \\
4.8 \\
10.8 \\
9.3 \\
10.8 \\
22.2 \\
9.1 \\
0.144\end{array}$ & $\begin{array}{c}8.7 \\
19.0 \\
26.2 \\
20.5 \\
19.8 \\
15.4 \\
21.7 \\
0.092\end{array}$ & $\begin{array}{l}0.26(0.07 \text { to } 0.75) \\
0.66(0.41 \text { to } 1.06) \\
1.00 \text { (reference group) } \\
0.73 \text { (0.50 to } 1.07) \\
0.67(0.38 \text { to } 1.17)\end{array}$ \\
\hline
\end{tabular}


There was no increase in atopy in infants of lower birth weight and no correlation between birth weight and specific atopy to house dust mites $(p=0.29)$ or cats $(p=0.24)$ in the whole cohort or in either sex.

\section{MULTIVARIATE ANALYSIS}

If both parents reported asthma, the OR for symptoms of asthma at any age to 18 years was increased (3.24, 95\% CI 1.30 to 8.07 , $\mathrm{p}=0.01)$ as was the risk for airway hyperresponsiveness $(2.82,95 \%$ CI 1.15 to $6.87, \mathrm{p}=$ $0.02)$. Airway hyper-responsiveness was also related to paternal hay fever (OR $1.34,95 \% \mathrm{CI}$ 1.04 to $1.73, p=0.03$ ) and to asthma or hay fever in either parent (OR 1.46, 95\% CI 1.18 to $1.79, \mathrm{p}=0.0004)$.

By logistic regression, male sex increased the ORs for the development of atopy $(1.43,95 \%$ CI 1.20 to $1.69, \mathrm{p}=0.0001)$, sensitivity to house dust mites $(1.41,95 \%$ CI 1.16 to 1.71 , $\mathrm{p}=0.0005)$, sensitivity to cats $(1.32,95 \% \mathrm{CI}$ 1.00 to $1.75, \mathrm{p}=0.05$ ), and airway responsiveness at any age from 9 to 15 years $(1.24,95 \%$ CI 1.03 to $1.49, \mathrm{p}=0.02$ ). There was a nearly significant trend for boys to have an increased OR for symptoms of asthma reported at age 9 years $(1.28,95 \%$ CI 0.99 to $1.65, \mathrm{p}=0.06)$

Birth in the winter season increased the risk of sensitisation to cats (OR 1.92, 95\% CI 1.26 to $2.93, p=0.003$ ) relative to those born in spring. Birth weight over $4000 \mathrm{~g}$ reduced the likelihood of sensitisation to cats (OR 0.17 , $95 \%$ CI 0.03 to $0.85, p=0.03$ relative to a reference birth weight of 3000-3499 g) and perhaps of atopy in general (OR $0.64,95 \% \mathrm{CI}$ 0.40 to $1.03, p=0.07$ ), but had no effect on the risks for sensitisation to house dust mites. Among children at higher risk of sensitisation (those with parental asthma or hay fever), birth in autumn and winter increased the risk of developing house dust mite allergy (34.2 $v$ $18.7 \%, \mathrm{p}=0.040$ ).

There was no consistent independent effect of socioeconomic status on any of the outcome variables.

\section{Discussion}

In this cohort of over 1000 children followed up for 18 years the strongest predictor for childhood atopy, airway hyper-responsiveness, and symptoms of asthma was family history, especially of maternal asthma and atopy. Male sex increased the risk of atopy and airway hyper-responsiveness, but was less strongly associated with symptoms, especially during late adolescence. Symptoms were also associated with substantial exposure to passive smoke. Our findings confirm and extend those reported from a longitudinal study of children from birth to age 6 years in Tucson, Arizona. ${ }^{44}$

Parental asthma increases the OR for asthma to as much as 2.6..$^{57-30}$ Maternal asthma is generally a stronger predictor of childhood asthma ${ }^{15} 45$ than paternal asthma. ${ }^{335}$ Our study differs from some in finding no significant effect of paternal asthma. This may reflect a greater uncertainty regarding a diagnosis of asthma in men because of the higher preva- lence of smoking and may also be influenced by the fact that the paternal history was usually obtained from the mother rather than directly from the father. We have confirmed that parental asthma is predictive of airway hyperresponsiveness in children. ${ }^{29} 46$ In other studies parental atopy increased the risk of atopy in children two to three times, ${ }^{5747}$ but we found on average only a 1.3-fold increase, increasing to 1.6-fold if both parents had hay fever (table 1).

A small but significant effect of maternal smoking was evident in this study with an impact seen on the early development of wheezing symptoms, as also reported in the Tucson longitudinal study, ${ }^{44}$ but less or no effect in older children. In part this may reflect an adverse effect of passive smoking on the smaller airways of young infants, with less adverse effects as lung growth occurs. ${ }^{48}$ We have shown, however, in earlier publications from our study that, using the random effects model, the impairment of lung function of wheezing children exposed to passive cigarette smoking worsens, whereas initially impaired lung function in wheezing children not exposed to smoke tends to return to normal by the age of 15 years. ${ }^{49}$

In another study of 8 to 13 year old children in New Zealand there was an increased OR for current wheeze $(1.4,95 \%$ CI 1.0 to 2.1$)$ if the primary care giver had smoked since the child's birth, but no increased risk from the mother smoking in pregnancy. ${ }^{17}$ In the UK National Cohort maternal smoking of more than 15 cigarettes daily and low birth weight were the major correlates of wheezing. ${ }^{30}$ After adjustment for these factors, all other putative risk factors (socioeconomic status, maternal age, breast feeding) became insignificant. The intensity of exposure to maternal smoke is important in determining the risk of childhood wheezing. Infante-Rivard showed that maternal smoking of over 20 cigarettes daily, when compared with no smoking, had an OR of 2.77 (95\% CI 1.36 to 5.66 ), whereas when all smoking was analysed together, no significant effect was found. ${ }^{3}$ In our study, although we were unable to show risks as high as these, similar trends are evident, adding further to concerns that parental smoking is a substantive cause of respiratory morbidity in children.

We did not find consistent associations between month or season of birth and atopy or symptoms of asthma, except that birth in the winter months increased the likelihood of sensitisation to cats and (in those at higher risk because of parental asthma or hay fever) to house dust mites. We suspect that these findings relate to a greater exposure to indoor allergens in the winter months when the infant is less likely to be taken outside for any prolonged period. Given the variable findings of many studies we suggest that reported associations between season of birth and development of atopy are likely to be local rather than universal in their applicability.

We were unable to confirm any effect of number of siblings on the development of atopy or asthma in this cohort, differing from 
both von Mutius et al who reported more atopy in first born children and Businco et al who found less asthma in first born children. Again, local environmental factors may affect exposures in different areas, explaining these apparent contradictions. New Zealand children may all be highly exposed to allergens, particularly house dust mites, overpowering any sibling effects.

We confirmed the sex differences in risk for the development of asthma which had been identified in most previous studies. ${ }^{2122} 29343550$ In an Isle of Wight birth cohort boys had more asthma (OR 1.6) and more positive skin tests (OR 1.8) than girls, ${ }^{21}$ while among Danish children boys had increased wheezing in the first 18 months (OR 1.9). ${ }^{22}$ Among Australian children, more boys than girls showed airway responsiveness. $^{29}$

Our findings do not suggest a relation between atopy or asthma and birth weight. Seidman et $a l^{20}$ reviewed over 2000017 year old Israeli army recruits and, after adjustment for ethnicity, socioeconomic factors, paternal education, maternal age, and birth order, found that those with birth weights less than $2500 \mathrm{~g}$ were at increased risk of developing asthma. In that study, however, only boys were considered and asthma was diagnosed only where there was 'clear medical evidence of past or present bronchial disease as opposed to episodic attacks'. The higher prevalence of atopy in our median birth weight group is consistent with the higher prevalence of asthma and wheezing in that group. Our findings are similar to those of Kelly et al, ${ }^{51}$ who found a trend towards less asthma in Merseyside children of lower birth weight.

In summary, we have shown in a longitudinal study of a birth cohort of over $1000 \mathrm{New}$ Zealand children that the family history of asthma and atopy is the strongest predictor of features of asthma and atopy in the child. Male gender, maternal smoking, and birth in the winter months are also relevant risk factors for symptoms and certain allergen sensitivities, whereas birth weight, birth order, and socioeconomic status were not risk factors for asthma in this cohort. These findings suggest possible areas for intervention in children at risk of developing asthma because of parental atopy. These interventions would logically include the avoidance of maternal smoking during and after pregnancy, the reduction of exposure to relevant allergens, particularly house dust mites in children at risk and cats in all children, but the benefits of such interventions require further study.

This study was supported by the Health Research Council of New Zealand and the Otago Medical Research Foundation.

1 Strope GL, Stempel DA. Risk factors associated with the development of chronic lung disease in children. Pediat Clin North $A m$ 1984;31:757-71.
.

2 Morgan WJ, Martinez FD. Risk factors for developing wheezing and asthma in childhood. Pediatr Clin North Am 1992;39:1185-203.

3 Infante-Rivard C. Childhood asthma and indoor environmental risk factors. Am $\mathcal{F}$ Epidemiol 1993;137:834-44.

4 Strachan DP. Is allergic disease programmed in early life? Clin Exp Allergy 1994;24:603-5.
5 Dold S, Wist M, von Mutius E, Reitmeir P, Stiepel E Genetic risk for asthma, allergic rhinitis, and atopic dermaGenetic risk for asthma, allergic rhinitis
titis. Arch Dis Child 1992;67:1018-22.

6 Sherman CB, Tosteson TD, Tager IB, Speizer FE, Weiss ST. Early childhood predictors of asthma. Am $\mathcal{f}$ Epidemiol 1990;132:83-95.

7 Kuehr J, Frischer T, Karmaus W, et al. Early childhood risk factors for sensitization at school age. $\mathcal{f}$ Allergy Clin Immunol 1992;90:358-63.

8 von Mutius E, Martinez FD, Fritzsch C, Nicolai T, Reitmeir $P$, Thiemann $\mathrm{HH}$. Skin test reactivity and number of siblings. $B M F$ 1994;308:692-5

9 Businco L, Cantani A, Farinella F, Businco E. Month of birth and grass pollen or mite sensitization in children with respiratory allergy: a significant relationship. Clin Allergy 1988;18:269-74.

10 Aberg N. Birth season variation in asthma and allergic rhinitis. Clin Exp Allergy 1989;19:643-8.

11 Korsgaard J, Dahl R. Sensitivity to house dust mite and grass pollen in adults. Influence of the month of birth. Clin Allergy 1983;13:529-36.

12 Bisgaard H, Dalgaard P, Nyboe J. Risk factors for wheezing during infancy. A study of 5953 infants. Acta Paediatr Scand 1987;76:719-26.

$13 \mathrm{Kemp}$ AS. Relationship between the time of birth and the development of immediate hypersensitivity to grass-pollen antigens. Med $\Im$ Aust 1979;i:263-4.

14 Couriel JM. Passive smoking and the health of children. Thorax 1994;49:731-4.

15 Soyseth V, Kongerud J, Boe J. Postnatal maternal smoking increases the prevalence of asthma but not of bronchial hyperresponsiveness or atopy in their children. Chest 1995; 107:389-94.

16 Soto-Quiros M, Bustamante M, Gutierrez I, Hanson LA, Strannegard II, Karlberg J. The prevalence of childhood asthma in Costa Rica. Clin Exp Allergy 1994;24:1130-6.

17 Shaw R, Woodman K, Crane J, Moyes C, Kennedy J, Pearce N. Risk factors for asthma symptoms in Kawerau children. N Z Med ₹ 1994;107:387-91.

18 Weitzman M, Gortmaker S, Walker DK, Sobol A. Maternal smoking and childhood asthma. Pediatrics 1990;85:505-11.

19 Galdes-Sebaldt M, Sheller JR, Grogaard J, Stahlman M. Prematurity is associated with abnormal airway function in Prematurity is associated with abnormal airway
childhood. Pediatr Pulmonol 1989;7:259-64.

20 Seidman DS, Laor A, Gale R, Stevenson DK, Danon YL. Is low birth weight a risk factor for asthma during adolescence? Arch Dis Child 1991;66:584-7.

21 Arshad SH, Stevens M, Hide DW. The effect of genetic and environmental factors on the prevalence of allergic disorders at the age of two years. Clin Exp Allergy 1993;23: 504-11.

22 Halken S, Host A, Husby S, Hansen LG, Osterballe O, Nyboe J. Recurrent wheezing in relation to environmental risk factors in infancy. Allergy 1991;46:507-14.

23 Gortmaker SL, Walker DK, Jacobs FH, Ruch-Ross H. Parental smoking and the risk of childhood asthma. Am $\mathcal{f}$ Public Health 1982;72:574-9.

24 Taussig LM, Holberg CJ, Wright AL. Prospective study of wheezing during the first 3 years of life. Am Rev Respir Dis 1993;147:A375

25 Forastiere F, Agabiti N, Corbo GM, et al. Passive smoking as a determinant of bronchial responsiveness in children. $\mathrm{Am}$ f Respir Crit Care Med 1994;149:365-70.

26 Peat JK, Woolcock AJ, Leeder SR, Blackburn CRB. Asthma and bronchitis in Sydney schoolchildren. II. The effect of social factors and smoking on prevalence. Am $\mathcal{F}$ Epidemiol 1980;111:728-35.

27 Dawson B, Horobin G, Illsley R, Mitchell R. A survey of childhood asthma in Aberdeen. Lancet 1969;i:827-30.

28 Horwood LJ, Fergusson DM, Shannon FT. Social and familial factors in the development of early childhood familial factors in the developm

29 Peat JK, Britton WJ, Salome CM, Woolcock AJ. Bronchial hyper-responsiveness in two populations of Australian schoolchildren. II. Relative importance of associated factors. Clin Allergy 1987;17:283-90.

30 Lewis S, Richards D, Bynner J, Butler N, Britton J. Prospective study of risk factors for early and persistent wheezing in childhood. Eur Respir ₹ 1995;8:349-56.

31 Duffy DL, Mitchell CA. Respiratory symptoms in Queensland schoolchildren: an association between month of birth and respiratory illness. Clin Exp Allergy 1991;21:231-3.

32 Croner S, Kjellman N-IM. Natural history of bronchial asthma in childhood. A prospective study from birth up to asthma in childhood. A prospective study

33 Mitchell EA. Month of birth and admission to hospital for asthma. Aust N Z Med F 1983;13:291-2.

34 Kuehr J, Frischer T, Karmaus W, Meinert R, Barth R, Urbanek $R$. Clinical atopy and associated factors in primary-school pupils. Allergy 1992;47:650-5.

35 Frischer T, Kuehr J, Meinert R, Karmaus W, Urbanek R. Risk factors for childhood asthma and recurrent wheezy bronchitis. Eur f Pediatr 1993;152:771-5.

36 Chan KN, Elliman A, Bryan E, Silverman M. Clinical significance of airway responsiveness in children of low birthweight. Pediatr Pulmonol 1989;7:251-8.

37 Backer V, Ulrik SU, Hansen KK, Laursen EM, Dirksen A, Bach-Mortensen N. Atopy and bronchial responsiveness in a random population sample of 527 children and adolescents. Ann Allergy 1992;69:1 16-22.

38 Ninan TK, Russell G, Russell D, MacDonald L. Parental atopy, birth events, early feeding practices, and the prevalence of atopy amongst 8-13 year old school children. Eur Respir $₹$ 1993;6:234s. 
39 Hood LJ, Faed JA, Silva PA, Buckfield PM. Breast feeding and some reasons for electing to wean the infants: a report from the Dunedin Multidisciplinary Child Development Study. $N Z$ Med $¥$ 1978;88:273-6.

40 Sears MR, Jones DT, Silva PA, Simpson A, Williams SM Asthma in seven year old children: a report from the Dunedin Multidisciplinary Child Development Study. NZMed f 1982;713:533-6.

41 Jones DT, Sears MR, Holdaway MD, Hewitt CJ, Flannery EM, Herbison GP. Childhood asthma in New Zealand. Br f Dis Chest 1987;81:332-40.

42 Sears MR, Jones DT, Holdaway MD, et al. Prevalence of bronchial reactivity to inhaled methacholine in New bronchial reactivity to inhaled methach

43 Sears MR, Herbison GP, Holdaway MD, Hewitt CJ, Flannery EM, Silva PA. The relative risks of sensitivity to grass pollen, house dust mite and cat dander in the development of childhood asthma. Clin Exp Allergy 1989;19:419-24

44 Martinez FD, Wright AL, Taussig LM, et al. Asthma and wheezing in the first six years of life. $N$ Engl $\mathcal{f} \mathrm{Med}$ 1995;332:133-8.
45 Aberg N. Familial occurrence of atopic disease: genetic versus environmental factors. Clin Exp Allengy 1993;23:829-34.

46 Young S, Le Souef PN, Geelhoed GC, et al. The influence of a family history of asthma and parental smoking on airway responsiveness in early infancy. $N$ Engl $\mathcal{F}$ Med 1991;324: 1168-73.

47 Davis JB, Bulpitt CJ. Atopy and wheeze in children according to parental atopy and family size. Thorax 1981;36:185-9.

48 Clarke JR, Salmon B, Silverman M. Bronchial responsiveness in the neonatal period as a risk factor for wheezing in ness in the neonatal period as a risk factor for wheezing
infancy. Am $\mathcal{F}$ Respir Crit Care Med 1995;151:1434-40.

49 Sherrill DL, Martinez FD, Lebowitz MD, et al. Longitudinal effects of passive smoking on pulmonary function in New effects of passive smoking on pulmonary function in

50 Anderson HR, Bland JM, Peckham CS. Risk factors for asthma up to 16 years of age. Evidence from a national cohort study. Chest 1987;91:127S-30S.

51 Kelly YJ, Brabin BJ, Milligan P, Heaf DP, Reid J, Pearson MG. Maternal asthma, premature birth, and the risk of respiratory morbidity in schoolchildren in Merseyside. Thorax 1995;50:525-30. 